\title{
Prevalence of Helicobacter pylori among Sudanese patients diagnosed with colon polyps and colon cancer using immunohistochemistry technique
}

\author{
Aziza K. Mohamed ${ }^{1}$, Nazik M. Elhassan ${ }^{1}$, Zahra A. Awhag ${ }^{1}$, Fadwa S. Ali', Eman T. Ali ${ }^{1,2}$, Najwa A. Mhmoud ${ }^{3,4}$, \\ Emmanuel E. Siddig ${ }^{3,5,6}$, Rowa Hassan ${ }^{3}$, Eiman S. Ahmed ${ }^{3}$, Azam Fattahi' ${ }^{7}$, Ayman Ahmed ${ }^{8}$, \\ Mohamed S. Muneer ${ }^{9,10,11}$, Hussam A. Osman ${ }^{12}$, Nouh S. Mohamed ${ }^{13,14,15^{*}}$ (I) and Ali M. M. Edris 1,16
}

\begin{abstract}
Objectives: Infection with the bacteria Helicobacter pylori has been classified as class one carcinogen associated with increasing susceptibility of gastritis and gastric carcinoma. This study is aiming at investigating the prevalence of $H$. pylori among colon polyps and colon cancer patients. A descriptive cross-sectional hospital-based study was conducted between February and June 2017. Sixty-nine formalin-fixed paraffin blocks collected from colon polyps and colon cancer patients to detect $H$. pylori using immunohistochemistry technique.

Results: Of the 69 patients included in the study, 39 (56.5\%) males and 30 (43.5\%) were females, their age ranged from 21 to 80 years with a mean age of $47.1 \pm 19.7$. Of the 69 colon polyps and colon cancer patients, 44 (63.8\%) were diagnosed as adenocarcinoma, 10 (14.5\%) colitis, 15 (21.7\%) juvenile polyposis syndrome. The results of immunohistochemistry technique showed the presence of 16 (23.2\%) positive patients for $\mathrm{H}$. pylori infection. Of these 16, 13 (81.3\%) patients were diagnosed with adenocarcinoma and 3 (18.7\%) patients were diagnosed with juvenile polyps. The results of $\mathrm{H}$. pylori detection among the different colon polyps and colon cancer patients were showing a statistically significant association for H. pylori infection and adenocarcinoma, P value 0.028.
\end{abstract}

Keywords: Colon polyps, Colon cancer, Helicobacter pylori, Immunohistochemistry

\section{Introduction}

Colorectal cancer (CRC) is accounted as the third most common malignancy and the third most common cause of death due to cancer in both men and women in the US [1]. CRC mostly arises from adenomatous polyps (adenomas) and from hyperplastic polyps [2, 3]. Early diagnosis and surgical removal of these polyps have associated with the decreased in the incidence of mortality [4-6].

\footnotetext{
*Correspondence: nouh_saad@outlook.com

${ }^{15}$ Department of Parasitology and Medical Entomology, Faculty of Medical Laboratory Sciences, Nile University, Khartoum, Sudan Full list of author information is available at the end of the article
}

Therefore, clinicians started to focus in recent years on the prevention measures that decrease the incidence of developing CRC; although, researchers started to explore the role of several infectious organism and their ability to increase or induce CRC [7-10]. For instance, many epidemiological studies have linked the infection of Helicobacter pylori to colorectal neoplasm either through high prevalence of $H$. pylori seropositivity among CRC or colorectal polyp patients [11-13], or through the presence of bacterial products and their trophic effects on colon mucosa [14-17]. Moreover, few studies have linked the presence of $H$. pylori in the stomach or colon with colon cancer and/or polyps [18-23].

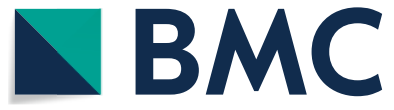

(c) The Author(s) 2020. This article is licensed under a Creative Commons Attribution 4.0 International License, which permits use, sharing, adaptation, distribution and reproduction in any medium or format, as long as you give appropriate credit to the original author(s) and the source, provide a link to the Creative Commons licence, and indicate if changes were made. The images or other third party material in this article are included in the article's Creative Commons licence, unless indicated otherwise in a credit line to the material. If material is not included in the article's Creative Commons licence and your intended use is not permitted by statutory regulation or exceeds the permitted use, you will need to obtain permission directly from the copyright holder. To view a copy of this licence, visit http://creativeco mmons.org/licenses/by/4.0/. The Creative Commons Public Domain Dedication waiver (http://creativecommons.org/publicdomain/ zero/1.0/) applies to the data made available in this article, unless otherwise stated in a credit line to the data. 
It is well known that $H$. pylori predisposes to develop gastric cancer precursor lesions, thus it has been classified as class 1 carcinogen [24]. A recent meta-analysis correlating between $H$. pylori and extra-gastric malignancies revealed a statistically significant relationship of $H$. pylori infection with both colon cancer and polyps [25]. Also, H. pylori infection linked with colorectal lesions appeared to be more common in African Americans compared to the Caucasian population in the US $[26,27]$.

Epidemiological studies have confirmed a causal relationship between $H$. pylori and gastric cancer, and the colonic phenotype of $H$. pylori-related intestinal metaplasia (IM) [28]. Thus, association of H. pylori in various gastrointestinal cancers has been investigated, moreover, Helicobacter DNAs were prevalent in more than $50 \%$ of hepatobiliary cancer cases [29]. Helicobacter species, which may colonize the biliary tract, have been implicated as a possible cause of hepatobiliary diseases ranging from chronic cholecystitis and primary sclerosing cholangitis to gall-bladder carcinoma and primary hepatic carcinomas [30]. Therefore, the hypothesis that $H$. pylori would also be associated with colon lesions needs to be investigated. In Sudan, no reports addressing this manner were existed. Previous studies investigating the seroprevalence of $H$. pylori among Sudanese using ELISA and rapid immunochromatographic tests for the detection of H. pylori IgM and IgG antibodies, reported a seroprevalence ranging from $20 \%$ up to $70 \%$ [31-34]. Therefore, the aim of this study was to investigate the presence of H. pylori infections among Sudanese patients diagnosed with colon polyps and colon cancer and to correlate between its presence and the type of the lesions.

\section{Main text}

\section{Materials and methods}

\section{Sample and data collection}

This is a preliminary, descriptive study aimed to investigate the frequency of $H$. pylori infections among Sudanese patients diagnosed with colon cancer. Data were collected from 69 patients attended the National Laboratory and Alrahma Laboratory between February and June 2017.

During colonoscopy, presence of abnormal tissue, such as clumps of cells; polyps, formed on the inside of the colon, the pathologists obtained colon biopsies. Colon biopsies were fixed with formalin and processed into paraffin embedded blocks. Formalin-fixed paraffin blocks were used for the immunohistochemical detection of $H$. pylori. Ethical approval was previously obtained by the pathologists of each hospital before colon polyps' biopsies were taken.

\section{Preparation of the formalin fixed paraffin blocks}

Four sections from each formalin-fixed paraffin block to increase detection sensitivity were obtained with a thickness of $4 \mu \mathrm{m}$ using Rotary microtome (LEICA RM2125RT). All sections were de-waxed with two changes of Xylene for $3 \mathrm{~min}$ and then dehydrated in descending concentrations of Methanol starting from absolute Methanol through 90\% and lastly, a concentration of $70 \%$ for $2 \mathrm{~min}$ in each concentration, and then washed using distilled water.

\section{Immunohistochemistry diagnosis}

Immunohistochemistry diagnosis was performed on all the obtained sections. Known gastric sections containing $H$. pylori infection was used as positive and negative controls; for the negative control the primary antibody incubation step was omitted. All sections were pretreated to retrieve antigens at $97{ }^{\circ} \mathrm{C}$ for $10 \mathrm{~min}$ in citrate buffer solution, and then sections were blocked by $3 \%$ Hydrogen peroxide and absolute Methanol for $20 \mathrm{~min}$ at humidified chamber. Afterward, sections were blocked into Bovine serum Albumin (Thermo Fisher Scientific, Germany). A rabbit polyclonal antibody ULC3R (BioGenex, USA) (prepared from tissue culture supernatant diluted in PBS, pH 7.6 containing 5\% BSA and $0.09 \%$ Sodium Azaide) against $H$. pylori was applied for $40 \mathrm{~min}$, then washed in buffer solution for $5 \mathrm{~min}$. Then, a polymer solution was applied for $15 \mathrm{~min}$, and washed in buffer solution for $5 \mathrm{~min}$. Chromogen solution was added for $10 \mathrm{~min}$, and washed in distilled water. Finally, Mayer's Hematoxylin was added for $2 \mathrm{~min}$, and then, sections were blued using running distilled water for $5 \mathrm{~min}$. After bluing, sections were dehydrated, cleared, and mounted in DPX. Prepared sections were investigated microscopically by two experts' pathologists blindly without knowing the duplication of slides sections of each patient using X40 lens. Results were recorded into categories of positive and negative results; the dot like shape denoted the coccoid form of the organism as describe previously [35-38].

\section{Statistical analysis}

Descriptive data were analyzed using the Statistical Package for Social Science (SPSS-v20). Pearson Chi-square test was used to test the association of $H$. pylori infection with the different types of lesions. A P value $<0.05$ was considered as a statistically significant.

\section{Results}

Of the 69 patients, there were 30 (43.5\%) females and 39 (56.5\%) males, their ages ranged from 21 to 80 years with a mean age $47.1 \pm 19.8$. $44(63.8 \%)$ patients were diagnosed with adenocarcinoma, 10 (14.5\%) patients were 
colitis, and 15 (21.7\%) patients were juvenile polyposis syndrome. No statistically significant was observed for the association of gender and the pathological condition of each patient, $\mathrm{P}$ value $=0.649$. Out of the 69 patients, $16(23.2 \%)$ patients were positive for $H$. pylori infection. These 16 positive patients included; 13 (81.3\%) patients diagnosed with adenocarcinoma and 3 (18.7\%) patients diagnosed with juvenile polyps. The correlation between presence of $H$. pylori infection and the histopathological condition of patients were positively correlated ( $\mathrm{P}$ value 0.028) (Table 1).

In respect to Immunohistochemistry diagnosis, the bacteria were prominent and easier to detect in the immune-stained sections in several patterns including organisms attached to the epithelial cells or within the superficial mucus. And in some cases, the bacteria were masked by inspissated mucus or being positioned flat and closely opposed to the epithelial surface. Regarding the morphological appearance of the organism; H. pylori stained brown in color and take a dot and small curved shape in different sizes (Fig. 1).

\section{Discussion}

The exact role of $H$. pylori in the induction of colon cancer is still a debate between the scientific researcher communities; this is attributed to the controversial results obtained. In previous studies, $H$. pylori were linked to the development of gastric cancer [39], while others reported paradoxical results showing no association between $H$. pylori and gastric cancer susceptibility [22, 40, 41]. However, reports from Sudan regarding the possible link between $H$. pylori and colon cancer are scarce. Therefore, in the present study, we examined the presence of $H$. pylori using immunohistochemistry technique on colon polyps and colon cancer lesions of Sudanese patients underwent colonoscopy.
The results obtained from this study showed a positive correlation between the presence of $H$. pylori infection and the histopathological diagnosis, as H. pylori was prevalent in higher frequency in patients diagnosed with adenocarcinoma compared to those diagnosed as juvenile polyposis syndrome, and the result was statistically significant. This result also agrees with studies conducted by Jones et al. and Grahn et al. they investigated the presence of $H$. pylori among 59 patients diagnosed with colon adenocarcinomas using immunohistochemistry technique, and 77 colon and rectum cancer patients using molecular technique, correspondingly [20, 39]. Jones et al., reported that $H$. pylori were detected in 10/59 adenocarcinoma cases which represent about $16.9 \%$ of the total cancer cases studied [39]. While, Grahn et al. showed that $H$. pylori were present in $27 \%$ of the patients; among the studied colon cancer, $H$. pylori were present in $11 / 42(26 \%)$ patients [20].

Although, several studies failed to demonstrate any association between H. pylori and colon cancer, or even if this microorganism can colonize the colon [42-46]. This could only be attributed to the ability of demonstrating the $H$. pylori bacteria, which was achieved by the aid of the immunohistochemistry technique that allowed a better localization of $H$. pylori within the various colon lesions of colitis, polyps, and adenocarcinoma included in this study.

Interestingly, several theories were proposed regarding the exact role by which $H$. pylori induced colon cancer, one hypothesis is that colon cancer can be induced by toxins produced by $H$. pylori; however, this theory was based only on serological data $[22,40,41,47]$. Furthermore, some studies showed that colitis and colon cancer were also developed in experimental mice models infected with $H$. hepaticus [46]. Accordingly, the development of colon cancer seems most likely due to

Table 1 Shows the correlation between gender, immunohistochemistry detection of $H$. pylori with the histopathological diagnosis

\begin{tabular}{|c|c|c|c|c|c|}
\hline & \multicolumn{3}{|c|}{ Histopathological Diagnosis } & \multirow[t]{2}{*}{ Total } & \multirow[t]{2}{*}{$P$ value } \\
\hline & Adenocarcinoma & $\begin{array}{l}\text { Juvenile polyposis } \\
\text { syndrome }\end{array}$ & Colitis & & \\
\hline \multicolumn{6}{|l|}{ Gender } \\
\hline Male & $23(58.9 \%)$ & $10(25.6 \%)$ & $6(15.5 \%)$ & $39(56.5 \%)$ & 0.649 \\
\hline Female & $21(70.0 \%)$ & $5(16.7 \%)$ & $4(13.3 \%)$ & $30(43.5 \%)$ & \\
\hline Total & $44(63.8 \%)$ & $15(21.7 \%)$ & $10(14.5 \%)$ & 69 (100\%) & \\
\hline \multicolumn{6}{|c|}{ Immunohistochemistry of H. pylori } \\
\hline Negative & $31(58.5 \%)$ & $12(22.6 \%)$ & $10(18.9 \%)$ & $53(76.8 \%)$ & 0.028 \\
\hline Positive & $13(81.3 \%)$ & $3(18.7 \%)$ & $0(0.0 \%)$ & $16(23.2 \%)$ & \\
\hline Total & $44(63.8 \%)$ & $15(21.7 \%)$ & $10(14.5 \%)$ & $69(100 \%)$ & \\
\hline
\end{tabular}



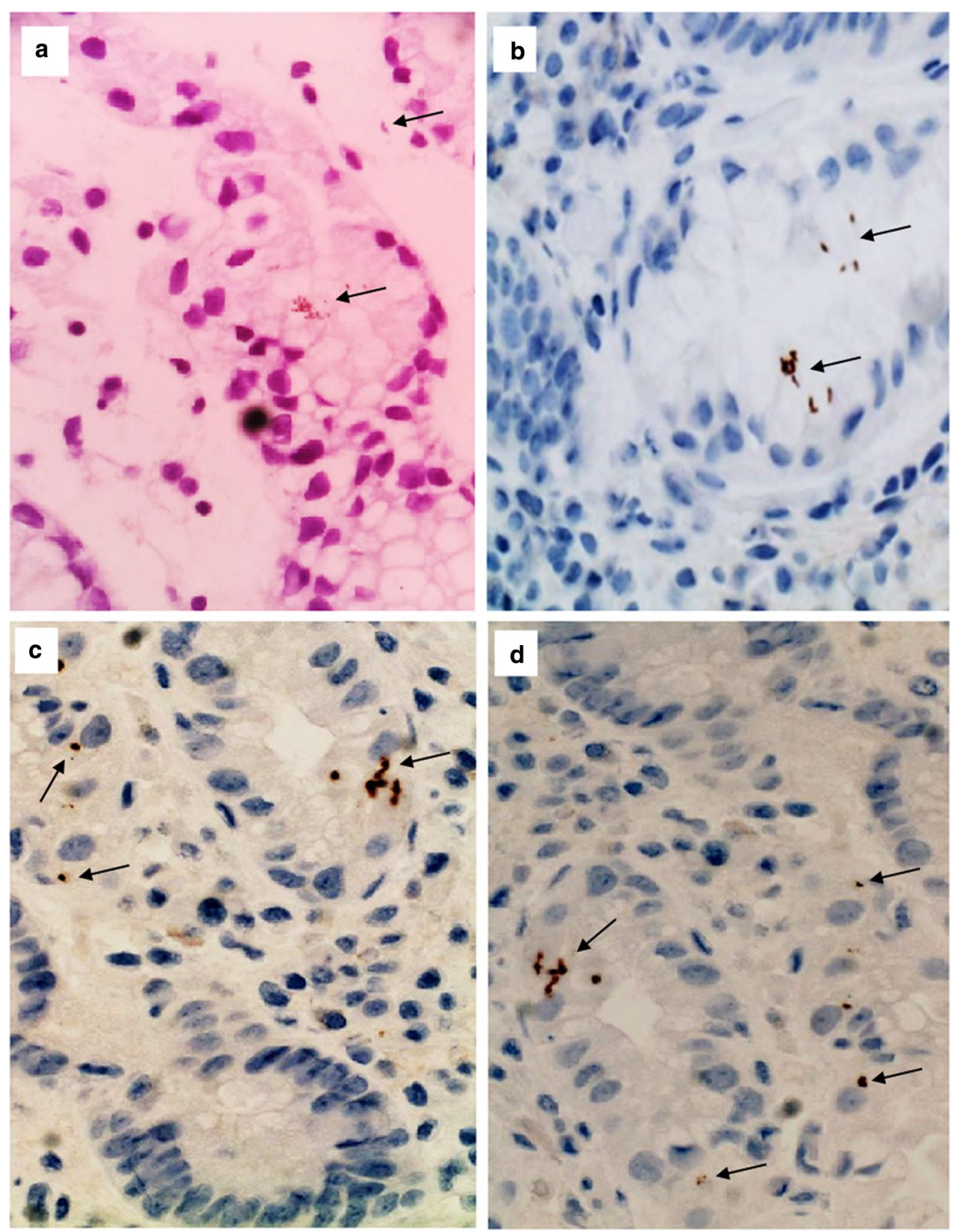

Fig. 1 Detection of H. pylori using IHC staining technique. a Indicates positive control tissue section of known gastric biopsy infected with H. pylori. b-d Indicates tissue sections of patients diagnosed with colon polyps and colon cancer. Black arrows indicate H. pylori stained brown in color and take a dot and small curved shapes in different sizes

the interaction between toxins produced by the bacteria and the immune cells of the mice [46]. Therefore, the results we obtained from our study showing that $H$. pylori were present, nevertheless, it means that $H$. pylori infection is responsible for the induction and the development of colon cancer, since the presence of $H$. pylori could be encountered as post-cancer incidence. This however, still requires more complicated experimental studies to investigate this hypothesis; yet, the role of H. pylori cannot be excluded due to this hypothesis. Therefore, this preliminary report needs further advanced experimental investigations to enable the 
determination on the exact mechanisms by which $H$. pylori can induce colon cancer.

\section{Conclusion}

This study was able to demonstrate the presence of $H$. pylori in colon polyps and colon cancer using immunohistochemistry marker, besides the significant association in the presence of $H$. pylori with colon adenocarcinoma, indeed further studies are required to elaborate more in-depth about the exact role of $H$. pylori in the development of colon cancer.

\section{Limitations}

- In this study the sample size studied was relatively small, but still a significant association was observed. A bigger sample size of colon cancer lesions and benign colon lesions; non cancer lesions, should be included in future studies to determine the significant association of $H$. pylori with adenocarcinoma among the Sudanese patients diagnosed with colon cancer.

\section{Abbreviations}

DNA: Deoxyribonucleic acid; CRC: Colorectal cancer; IM: Intestinal metaplasia.

\section{Acknowledgements}

The authors are grateful to the patients and the staff at the National Laboratory and Al-Rahma Laboratory for their continued collaboration and generous hospitality.

\section{Authors' contributions}

AKM, NME, ZAA, FSA, EES and AMME provided conceptual framework for the project. AKM, NME, ZAA, FSA, ETA, NAM, RH, HAO and ESA participated in the preparation of the samples and performed the diagnosis. NSM, AF, EES, MSM $A A$, and $A M M E$ performed the data analysis and guidance for data interpretation. AA, MSM, ETA, NAM, RH, ESA, AF, and NSM drafted the manuscript. All authors read and approved the final manuscript.

\section{Funding}

Not applicable.

\section{Availability of data and materials}

The datasets used and/or analyzed during the current study are available from the corresponding author on reasonable request.

\section{Ethics approval and consent to participate}

The study ethical clearance was obtained from University of Khartoum, Faculty of Medical Laboratory Sciences ethical review board. Informed consent was obtained from each participant prior to enrollment using writing and verbal informed consent.

\section{Consent to publish}

Not applicable.

\section{Competing interests}

The authors declare that they have no competing interests.

\section{Author details}

${ }^{1}$ Department of Histopathology and Cytology, Faculty of Medical Laboratory Sciences, University of Khartoum, Khartoum, Sudan. ${ }^{2}$ Department of Histopathology and Cytology, Faculty of Medical Laboratory Sciences, National University, Sudan, Khartoum, Sudan. ${ }^{3}$ Mycetoma Research Center, University of Khartoum, Khartoum, Sudan. ${ }^{4}$ Department of Microbiology and Immunology, Faculty of Medical Laboratory Sciences, University of Khartoum, Khartoum, Sudan. ${ }^{5}$ School of Medicine, Nile University, Khartoum, Sudan. ${ }^{6}$ Department of Histopathology and Cytology, Alfarrabi College for Science and Technology, Khartoum, Sudan. ${ }^{7}$ Center for Research and Training in Skin Disease and Leprosy, Tehran University of Medical Sciences, Tehran, Iran.

${ }^{8}$ Department of Parasitology and Medical Entomology, Institute of Endemic Diseases, University of Khartoum, Khartoum, Sudan. ${ }^{9}$ Department of Neurology, Mayo Clinic, Jacksonville, FL, USA. ${ }^{10}$ Department of Radiology, Mayo Clinic, Jacksonville, FL, USA. ${ }^{11}$ Department of Internal Medicine, Faculty of Medicine, University of Khartoum, Khartoum, Sudan. ${ }^{12}$ Biomedical Research Laboratory, Ahfad University for Women, Omdurman, Sudan. ${ }^{13}$ Molecular Biology Department, Alfarrabi College for sciences and Technology, Khartoum, Sudan. ${ }^{14}$ Department of Parasitology and Medical Entomology, Faculty of Medicine, Sinnar University, Sinnar, Sudan. ${ }^{15}$ Department of Parasitology and Medical Entomology, Faculty of Medical Laboratory Sciences, Nile University, Khartoum, Sudan. ${ }^{16}$ Faculty of Applied Medical Sciences, University of Bisha, Bisha, Kingdom of Saudi Arabia.

Received: 24 May 2020 Accepted: 26 June 2020

Published online: 06 July 2020

\section{References}

1. Jemal A, Siegel R, Xu J, Ward E. Cancer statistics, 2010. CA Cancer J Clin. 2010;60:277-300.

2. Hawkins NJ, Ward RL. Sporadic colorectal cancers with microsatellite instability and their possible origin in hyperplastic polyps and serrated adenomas. J Natl Cancer Inst. 2001;93:1307-13.

3. Jass JR. Hyperplastic-like polyps as precursors of microsatellite-unstable colorectal cancer. Am J Clin Pathol. 2003;119:773-5.

4. Kahi CJ, Imperiale TF, Juliar BE, Rex DK. Effect of screening colonoscopy on colorectal cancer incidence and mortality. Clin Gastroenterol Hepatol. 2009;7:770-5.

5. Levin B, Lieberman DA, McFarland B, Smith RA, Brooks D, Andrews KS, Dash C, Giardiello FM, Glick S, Levin TR. Screening and surveillance for the early detection of colorectal cancer and adenomatous polyps, 2008: a joint guideline from the American Cancer Society, the US Multi-Society Task Force on Colorectal Cancer, and the American College of Radiology. CA Cancer J Clin. 2008;58:130-60.

6. Winawer SJ, Zauber AG, Ho MN, O'brien MJ, Gottlieb LS, Sternberg SS, Waye JD, Schapiro M, Bond JH, Panish JF. Prevention of colorectal cancer by colonoscopic polypectomy. N Engl J Med. 1993;329:1977-81.

7. Burnett-Hartman AN, Newcomb PA, Potter JD. Infectious agents and colorectal cancer: a review of Helicobacter pylori, Streptococcus bovis, JC virus, and human papillomavirus. Cancer Epidemiol Prev Biomarkers. 2008;17:2970-9.

8. Meira LB, Bugni JM, Green SL, Lee C-W, Pang B, Borenshtein D, Rickman $\mathrm{BH}$, Rogers AB, Moroski-Erkul CA, McFaline JL. DNA damage induced by chronic inflammation contributes to colon carcinogenesis in mice. J Clin Investig. 2008;118:2516-25.

9. Parsonnet J. Bacterial infection as a cause of cancer. Environ Health Perspect. 1995;103:263-8.

10. Dejea C, Wick E, Sears CL. Bacterial oncogenesis in the colon. Future Microbiol. 2013:8:445-60.

11. Fujimori S, Kishida T, Kobayashi T, Sekita Y, Seo T, Nagata K, Tatsuguchi A, Gudis K, Yokoi K, Tanaka N. Helicobacter pylori infection increases the risk of colorectal adenoma and adenocarcinoma, especially in women. J Gastroenterol. 2005;40:887-93.

12. Zhao Y-s, Wang F, Chang D, Han B, You D-Y. Meta-analysis of different test indicators: Helicobacter pylori infection and the risk of colorectal cancer. Int J Colorectal Dis. 2008;23:875-82.

13. Zumkeller N, Brenner H, Chang-Claude J, Hoffmeister M, Nieters A, Rothenbacher D. Helicobacter pylori infection, interleukin-1 gene 
polymorphisms and the risk of colorectal cancer: evidence from a casecontrol study in Germany. Eur J Cancer. 2007;43:1283-9.

14. D'Onghia V, Leoncini R, Carli R, Santoro A, Giglioni S, Sorbellini F, Marzocca G, Bernini A, Campagna S, Marinello E. Circulating gastrin and ghrelin levels in patients with colorectal cancer: correlation with tumour stage, Helicobacter pylori infection and BMI. Biomed Pharmacother. 2007;61:137-41.

15. Georgopoulos SD, Polymeros D, Triantafyllou K, Spiliadi C, Mentis A, Karamanolis DG, Ladas SD. Hypergastrinemia is associated with increased risk of distal colon adenomas. Digestion. 2006;74:42-6.

16. Hartwich A, Konturek S, Pierzchalski P, Zuchowicz M, Labza H, Konturek P, Karczewska E, Bielanski W, Marlicz K, Starzynska T. Helicobacter pylori infection, gastrin, cyclooxygenase-2, and apoptosis in colorectal cancer. Int J Colorectal Dis. 2001;16:202-10.

17. Siddheshwar R, Gray J, Kelly S. Plasma levels of progastrin but not amidated gastrin or glycine extended gastrin are elevated in patients with colorectal carcinoma. Gut. 2001:48:47-52.

18. Bae RC, Jeon SW, Cho HJ, Jung MK, Kweon YO, Kim SK. Gastric dysplasia may be an independent risk factor of an advanced colorectal neoplasm. World J Gastroenterol WJG. 2009;15:5722.

19. Bulajic M, Stimec B, Ille T, Jesenofsky R, Kecmanovic D, Pavlov M, Ceranic M, Schneider-Brachert W, Lowenfels A, Maisonneuve P. PCR detection of Helicobacter pylori genome in colonic mucosa: normal and malignant. Prilozi. 2007;28:25-38

20. Grahn N, Hmani-Aifa M, Fransén K, Söderkvist P, Monstein H-J. Molecular identification of Helicobacter DNA present in human colorectal adenocarcinomas by $16 \mathrm{~S}$ rDNA PCR amplification and pyrosequencing analysis. J Med Microbiol. 2005:54:1031-5.

21. Jones NL, Day AS, Jennings HA, Sherman PM. Helicobacter pylori induces gastric epithelial cell apoptosis in association with increased Fas receptor expression. Infection immunity. 1999;67:4237-42.

22. Mizuno S, Morita Y, Inui T, Asakawa A, Ueno N, Ando T, Kato H, Uchida M, Yoshikawa T, Inui A. Helicobacter pylori infection is associated with colon adenomatous polyps detected by high-resolution colonoscopy. Int J Cancer. 2005;117:1058-9.

23. Soylu A, Ozkara S, Alıs H, Dolay K, Kalaycı M, Yasar N, Kumbasar AB. Immunohistochemical testing for Helicobacter pylori existence in neoplasms of the colon. BMC Gastroenterol. 2008;8:35.

24. Bulajic M, Stimec B, Jesenofsky R, Kecmanovic D, Ceranic M, Kostic N, Schneider-Brachert W, Lowenfels A, Maisonneuve P, Löhr J-M. Helicobacter pylori in colorectal carcinoma tissue. Cancer Epidemiol Prev Biomarkers. 2007;16:631-3.

25. Rokkas T, Sechopoulos P, Pistiolas D, Kothonas F, Margantinis G, Koukoulis G. The relationship of Helicobacter pylori infection and colon neoplasia, on the basis of meta-analysis. Eur J Gastroenterol Hepatol. 2013;25:1286-94.

26. Jemal A, Siegel R, Xu J, Ward E. Cancer statistics. CA Cancer J Clin. 2010:2010(60):277-300.

27. Malaty HM, Evans DG, Evans DJ Jr, Graham DY. Helicobacter pylori in Hispanics: comparison with blacks and whites of similar age and socioeconomic class. Gastroenterology. 1992;103:813-6.

28. Alfarouk KO, Bashir AH, Aljarbou AN, Ramadan AM, Muddathir AK, AlHoufie ST, Hifny A, Elhassan GO, Ibrahim ME, Alqahtani SS. The possible role of Helicobacter pylori in gastric cancer and its management. Front Oncol. 2019:9:75

29. Fukuda K, Kuroki T, Tajima Y, Tsuneoka N, Kitajima T, Matsuzaki S, Furui J, Kanematsu T. Comparative analysis of Helicobacter DNAs and biliary pathology in patients with and without hepatobiliary cancer. Carcinogenesis. 2002;23:1927-32.

30. Leong R, Sung J. Helicobacter species and hepatobiliary diseases. Aliment Pharmacol Ther. 2002;16:1037-45.
31. Salih KM, Elfaki OA, Hamid YH, Eldouch WM, Diab M, Abdelgadir SO. Prevalence of Helicobacter pylori among sudanese children admitted to a specialized children hospital. Sudanese J Paediatr. 2017;17:14.

32. Abdallah TM, Mohammed HB, Mohammed MH, Ali AAA. Sero-prevalence and factors associated with Helicobacter pylori infection in Eastern Sudan. Asian Pac J Trop Dis. 2014;4:115-9.

33. Abbas M, Sharif FA, Osman SM, Osman AM, El Sanousi SM, Magzoub M, Ibrahim ME. Prevalence and associated symptoms of Helicobacter pylori infection among schoolchildren in Kassala State, East of Sudan. Interdiscip Perspect Infect Dis. 2018. https://doi.org/10.1155/2018/4325752.

34. Osman NA, Ahmed AA, Ahmed M, Osman T. Seroprevalence of Helicobacter pylori among sudanese gastritis patients. Afr J Med Sci. 2016; 1.

35. Chan W-Y, Hui P-K, Leung K-M, Chow J, Kwok F, Ng C-S. Coccoid forms of Helicobacter pylori in the human stomach. Am J Clin Pathol. 1994;102:503-7.

36. Chaput C, Ecobichon C, Cayet N, Girardin SE, Werts C, Guadagnini S, Prévost M-C, Mengin-Lecreulx D, Labigne A, Boneca IG. Role of AmiA in the morphological transition of Helicobacter pylori and in immune escape. PLoS Pathog. 2006;2:e97.

37. Saito N, Oda H, Sato F, Kato M, Takeda H, Sugiyama T, Asaka M. Ultrastructure of Helicobacter pylori. J Gastroenterol Hepatol. 2000;15:H25-H25.

38. Ali ET, Fadul TM, Nasr MA, Siddig EE, Mohamed NS, Edris AMM. Comparison between immunohistochemical marker and conventional histochemical stains in detecting Helicobacter pylori. EC Microbiol. 2018;14(8):430-7.

39. Jones M, Helliwell P, Pritchard C, Tharakan J, Mathew J. Helicobacter pylori in colorectal neoplasms: is there an aetiological relationship? World J Surg Oncol. 2007;5:51.

40. Shmuely H, Passaro D, Figer A, Niv Y, Pitlik S, Samra Z, Koren R, Yahav J. Relationship between Helicobacter pylori CagA status and colorectal cancer. Am J Gastroenterol. 2001;96:3406.

41. Fireman Z, Trost L, Kopelman Y, Segal A, Sternberg A. Helicobacter pylori: seroprevalence and colorectal cancer. Isr Med Assoc J IMAJ. 2000;2:6-9.

42. Limburg PJ, Stolzenberg-Solomon RZ, Colbert LH, Perez-Perez Gl, Blaser MJ, Taylor PR, Virtamo J, Albanes D. Helicobacter pylori seropositivity and colorectal cancer risk: a prospective study of male smokers. Cancer Epidemiol Prev Biomarkers. 2002;11:1095-9.

43. Moss SF, Neugut Al, Garbowski GC, Wang S, Treat MR, Forde KA. Helicobacter pylori seroprevalence and colorectal neoplasia: evidence against an association. JNCI J Natl Cancer Inst. 1995;87:762-3.

44. Siddheshwar R, Muhammad K, Gray J, Kelly S. Seroprevalence of Helicobacter pylori in patients with colorectal polyps and colorectal carcinoma. Am J Gastroenterol. 2001;96:84.

45. Luzza F, Maletta M, Imeneo M, Monteleone G, Marasco R, Biancone L, Pallone F. Evidence against colonic mucosa colonisation by Helicobacter pylori Lack of a specific antibody response in homogenates of rectal endoscopic biopsies. Ital J Gastroenterol. 1996;28:447-51.

46. Bell S, Chisholm S, Owen R, Borriello S, Kamm M. Evaluation of Helicobacter species in inflammatory bowel disease. Aliment Pharmacol Ther. 2003;18:481-6.

47. Hsu W-Y, Lin C-H, Lin C-C, Sung F-C, Hsu C-P, Kao C-H. The relationship between Helicobacter pylori and cancer risk. Eur J Internal Med. 2014:25:235-40.

\section{Publisher's Note}

Springer Nature remains neutral with regard to jurisdictional claims in published maps and institutional affiliations. 